\title{
Sustainable livelihood approach for assessing the impacts of slaughterhouses on livelihood strategies among pastoralists in Kenya
}

\author{
Josphat Njenga Gichure ${ }^{1 *} \mathbb{B}$, Sarah Kangai Njeru² and Pius Mwangi Mathi ${ }^{3}$
}

\begin{abstract}
The social, physical, financial, natural, and human dimensions within slaughterhouses have taken a central position in diversifying livelihoods among pastoralists in the arid and semi-arid lands (ASALs) in Kenya. There is a need to expound on the literature about these dimensions and assess how they impact on livelihood strategies and outcomes. This research aimed to bring out how these dimensions impact livelihood strategies among Kenyan pastoralists using the sustainable livelihood approach. Qualitative data was collected from four counties in Kenya's ASALs predominantly inhabited by pastoralists, using focus group discussions, and narratives Observations were analysed using the RQDA package within the $\mathrm{R}$ statistical computing environment. The results revealed increasingly diversified social-economic activities, value addition of slaughter by-products, better rangeland management, and diversified diets. Gender, age, and roles significantly $(P<0.01)$ influenced the extent of diversification. Diversified social-economic activities and value addition directly impacted food security through increased utilization of slaughter by-products, provision of an alternative livelihood source, and better resilience during calamities. To conclude, social, economic, and human activities were central in diversified and advanced pastoral livelihoods.
\end{abstract}

Keywords: Diversification, Vulnerability and resilience, Dimensions of human well-being, Indigenous/ethnic products, Pastoral

\section{Introduction}

Sub-Saharan pastoral regions are sometimes considered vulnerable to economic/resource trends, economic shocks, natural shocks, conflicts, seasonal fluctuations in prices, production, health, and employment opportunities (Alinovi et al. 2010). With these calamities, up to 30\% of pastoral households are vulnerable to food insecurity, with the majority living in the arid and semi-arid lands (ASALs) (Connolly-Boutin and Smit 2016; FAO 2002; Huho et al. 2016; Krätli and Swift 2014; Lembara et al. 2011; Mayanja et al. 2015). Food insecurity is the inability to access safe,

\footnotetext{
* Correspondence: jngichure@gmail.com; jgichure@seku.ac.ke 'Department of Food Science, Nutrition and Technology, South Eastern Kenya University, P.O. Box 170-90200, Kitui, Kenya Full list of author information is available at the end of the article
}

preferred, and sufficient food for an active and healthy life (Napoli et al. 2011; Pérez-Escamilla et al. 2017; PinstrupAndersen 2009). Food insecurity is a multi-dimensional phenomenon brought about by multiple stresses such as social, economic, political, institutional, and biophysical (Jackson et al. 2020). The main economic activity in the sub-Saharan ASALs is pastoralism and agro-pastoralism. In Kenya there are an estimated six million pastoralists and agro-pastoralists, contributing about $10 \%$ to the country's gross domestic product (Krätli and Swift 2014; Musyoka et al. 2020; Nyariki and Amwata 2019; Opiyo et al. 2015).

Value addition of meat and slaughter by-products, together with application of indigenous knowledge systems, have been key in creating resilience among 
pastoral communities globally (Anderson 2015; Fernández-Giménez et al. 2017; Global Water Partnership Eastern Africa (GWPEA) 2015). Resilience is the ability of a socio-economic system to absorb shocks, reorganize through adaptation and transformation, and retain its initial function, structure, and identity (Walker et al. 2004).

In the past, the literature had delinked resilience, poverty, and food insecurities in fragile environments, but recently, a causal relationship between the three has been observed (Bhattacharya et al. 2004; Drewnowski and Specter 2004; Oluoko-Odingo 2011; Zezza and Tasciotti 2010). Sub-Saharan ASALs have been associated with dynamic social-economic relations, underperforming food production systems, unsustainable natural resource management, resource predation, institutional corruption, epidemic disease, and more exogenous hazards, such as drought, flooding, and wildfires (Lembara et al. 2011). Within the last two decades, models forecasting vulnerability have revealed adverse effects on food security (Campbell et al. 2016; Islam et al. 2016). Of great concern, though not extensively studied, is the role of slaughterhouses which have been focal to livestock value addition on pastoral livelihoods.

Various models have been used to measure livelihood strategies and outcomes among the marginalized communities in developing and emerging economies. Examples of such models are the sustainable livelihood approach, the livelihoods approach, and the livelihood vulnerability framework (Ansah et al. 2019; ConnollyBoutin and Smit 2016; FAO 2016; Quandt 2018; Sati and Vangchhia 2017). A common ground in these models is that livelihood outcomes are appraised from income and food access, dimensions of human wellbeing, social safety nets, and access to public services, with poverty and food insecurity being the outcomes. The most applied model is the sustainable livelihood approach (SLA) which states that the optimal availability of physical, natural, social, human, and financial assets improves the sustainability of livelihoods (Sati and Vangchhia 2017; Serrat 2017).

Diversification of activities and value addition of slaughter by-products have positively impacted livelihoods by improving well-being, incomes, and gender inclusiveness, thereby addressing food insecurity in ASALs (Little et al. 2001; Rojas-Downing et al. 2017). Previously, changes in nomadic lifestyles among pastoralists have been reported, with increasing ventures into agropastoralism, pasture production, sale of natural resources, natural resource management, and crafts (Headey et al. 2014). There exists limited empirical information on the impact of physical, natural, social, human, and financial assets within slaughterhouses on the livelihood strategies and outcomes in pastoral communities. Advancing knowledge on these assets within a slaughterhouse has improved our understanding of existing livelihood strategies and outcomes. Sustainable livelihood models have been applied to understand similar dimensions in farming systems (Sati and Vangchhia 2017). The model has also revealed the need to incorporate policy frameworks and institutional dimensions in addressing vulnerability in sub-Saharan Africa (Rass 2006). This study aims at appraising how physical, natural, social, human, and financial assets within slaughterhouses in the ASALs impact the livelihood strategies and outcomes among Kenyan pastoral communities.

\section{Methodology \\ Conceptual design}

The SLA was adopted to conceptualize this study as recommended by Sati and Vangchhia (2017) and Serrat (2017). The idea was to appraise how social, physical, financial, natural, and human assets within slaughterhouses impact the livelihood strategies to mitigate against vulnerability. Figure 1 shows our conceptual framework based on the SLA framework.

\section{Study area}

Data was collected from four administrative Counties in the ASALs which are predominantly inhabited by pastoral communities. Turkana, Garissa, Marsabit, and Kajiado. Figure 2 is a map of the study area, showing the vegetation cover.

\section{Study design}

A cross-sectional design approach was adopted, while focus group discussion (FGD) guides collected qualitative data, as recommended for cultural and social studies (Saukko 2018; Degeling and Rock 2020). In total, five FGDs were conducted in each County. A homogeneous sampling scheme was used to identify eight to 12 participants as recommended (Onwuegbuzie and Frels 2015). The following roles were used to assign eight participants: (i) butcher of red meat, (ii) butcher of raw slaughter by-product handler, (iii) veterinary officer, (iv) community leader, (v) cleaner, (vi) meat/slaughter byproduct bulk trader, (vii) meat/slaughter by-product bulk retailer, and (viii) non-meat trader. In addition, a maximum of four others were included, one from each category to balance the gender and age of the participants. A set of questions (see Appendix) guided the discussions, with the questions covering vulnerability, livelihood assets, and livelihood strategies and linking these to livelihood outcomes. The data collected was triangulated using narratives with selected individuals found in the slaughterhouses but not part of the FGDs and direct observation of activities. 


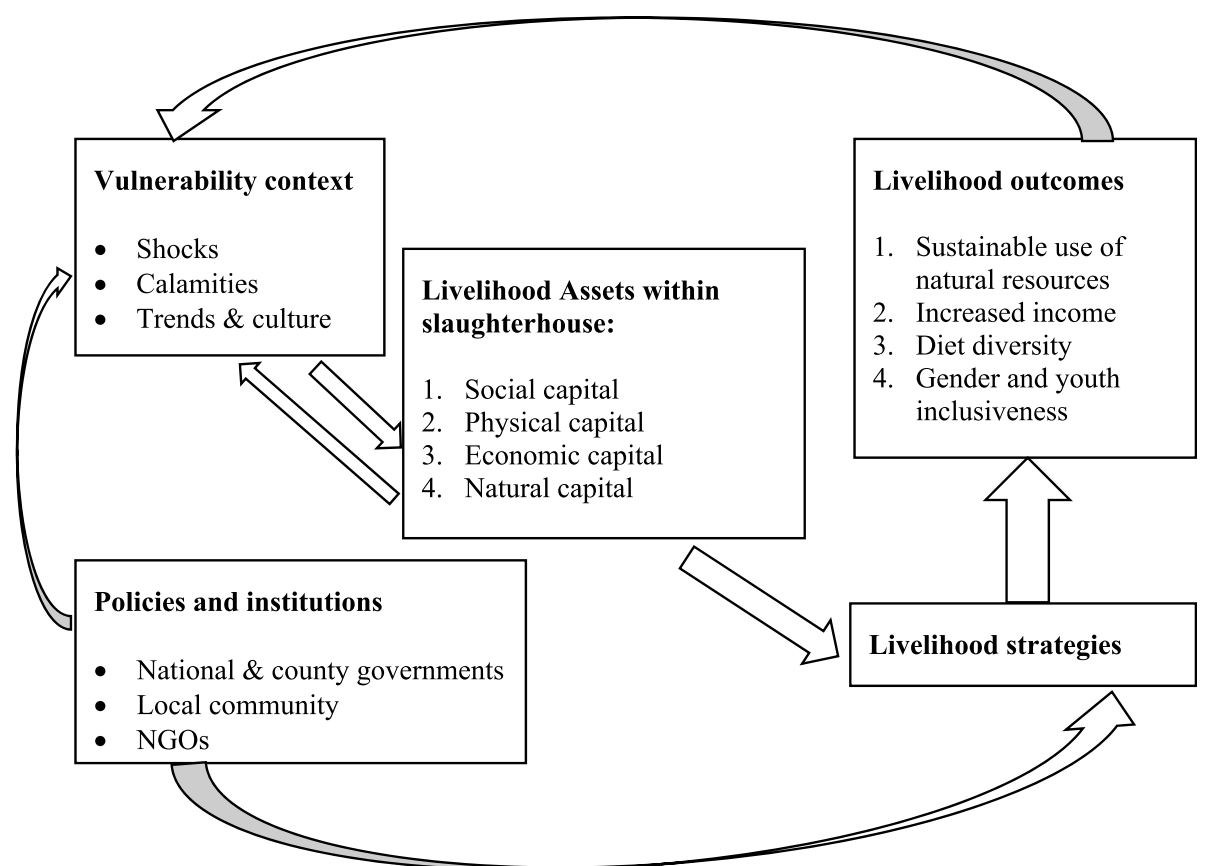

Fig. 1 The conceptual framework based on sustainable livelihoods approach model. modified from Serrat (2017)

\section{Data analysis}

The qualitative data collected was analysed using the RQDA (version 0.3.1) package within the R (Version 3.5.1) statistical computing environment as recommended (Chandra and Shang 2017; Degeling and Rock 2020). Thematic analysis was done as recommended (Estrada 2017; Braun and Clarke 2006, b). The recorded focus group discussions were translated and transcribed from the local dialects into English and then imported into the RQDA package. After a preliminary analysis of the data, four major categories from the FGDs' responses were identified: (a) physical dimension of human well-being within slaughterhouses, (b) economic dimension of human wellbeing within slaughterhouses, (c) social dimension of human well-being within slaughterhouses, and (d) rangeland management from slaughterhouse dimensions. During coding, theoretical themes were based on the authors' previous experiences in the pastoral areas. Phrases from a theme were then highlighted and pulled to the appropriate nodes as the RQDA package retrieved, compared, and linked the data. Attributes and descriptive information on age, gender, prices, and role/occupation were also highlighted. The data was then exported for further analysis using Microsoft Excel $^{\circledR} 2010$.

\section{Results and discussion}

\section{The physical dimension of human well-being within} slaughterhouses

The majority of the slaughterhouses were enclosed, although some open-air slaughter slabs were seen in the remote towns in the ASALs. Ownership was mainly by the local community, but management was by the County governments under the devolved Ministry of Agriculture, Livestock and Fisheries with a public veterinarian in charge of meat inspection. Figure 3 shows a pictorial representation of a slaughter slab for camel and cattle and an enclosed slaughterhouse for sheep and goats in Garissa County.

\section{The economic dimension of human well-being within slaughterhouses}

The prices of meat were based on its appearance, mainly size and fat marbling, with the average wholesale prices of camel meat, beef, and sheep/goat meat being USD 3.0 $(P<0.1$; range $2.8-3.6)$ per $\mathrm{kg}$ USD $2.5(P<0.01$; range 2.3-2.7) per $\mathrm{kg}$, and USD $2.8(P<0.01$; range $2.7-3.0)$ per $\mathrm{kg}$, respectively. The wholesale price of raw slaughter by-products was dependent on the specific organ. The wholesale price of the bovine head was USD2.0 $(P>0.1$; range 1.8-2.5) per piece; bovine hooves were USD0.2 $(P<0.01$; range $0.2-0.3)$ per piece; and organs such as the lungs, spleens, pancreases, tripe, intestines, and hearts were USD1.2 $(P>0.1$; range $0.9-2.1)$ per $\mathrm{kg}$, and the liver and kidneys USD2.0 $(P>0.1$; range $1.8-2.3)$, while the testicles and colon cost USD0.1 $(P<0.001$; range $0.1-0.1)$ per piece. It was noted that diversification had increased diet diversity among residents through increases in consumption of edible by-products as previously reported in similar studies (Gichure et al. 2014; 


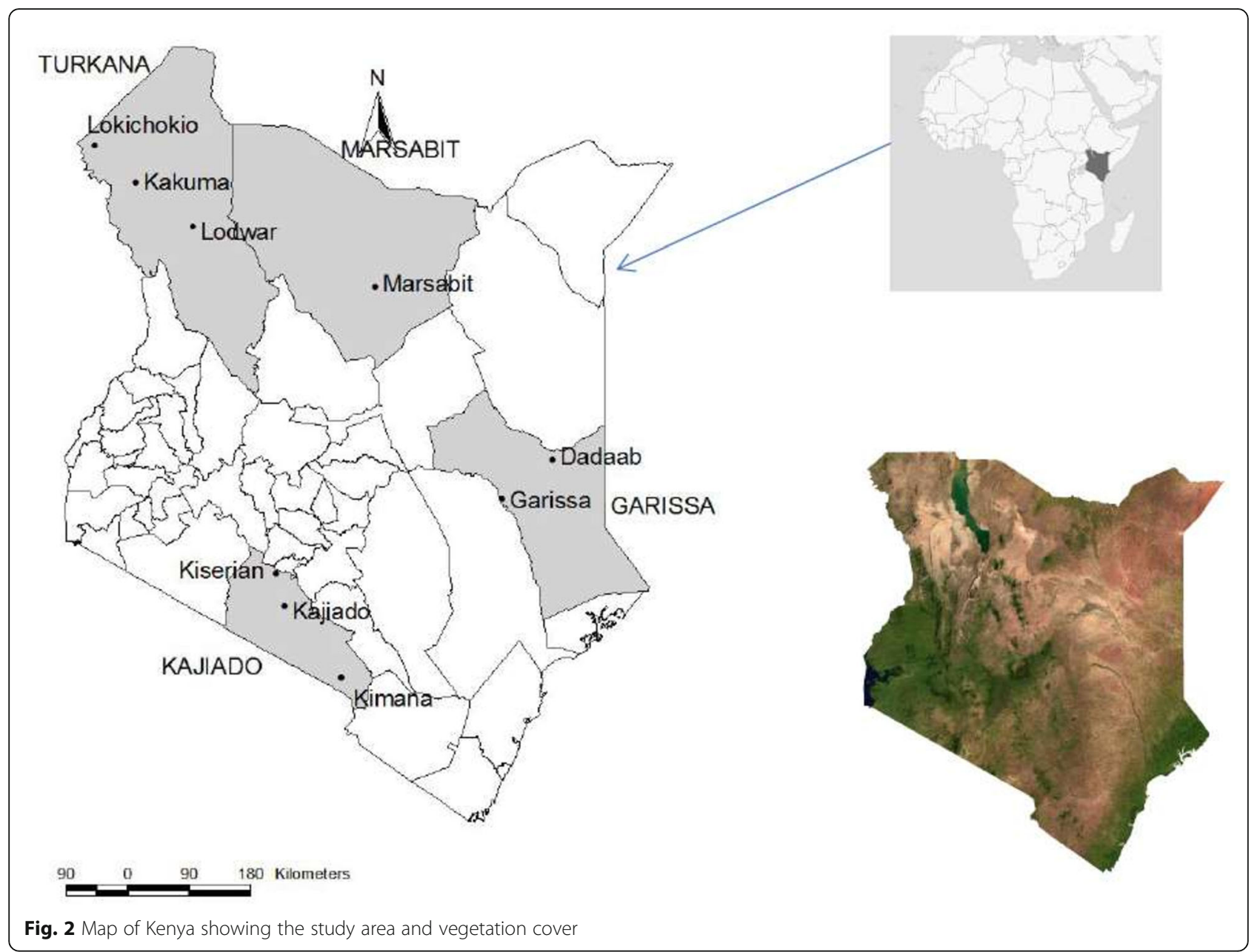

Headey et al. 2014; Mathi et al. 2016; Mayanja et al. 2015; Megersa et al. 2014).

To maintain the slaughterhouse, a fee was charged for each animal slaughtered; cattle and camel cost an average USD1.8 $(P<0.01$; range $1.2-2.0)$, and USD 0.6 $(P<0.01$; range $0.5-0.6)$ was paid for sheep/goat. Documentation of these fees was done by the veterinary officer with the collected revenue used to facilitate meat inspection and waste management. The slaughterhouse caretakers, mostly from the local community, were the custodians of all documentations. Also, the owners of the animals slaughtered had to pay an extra charge to the butchers. This charge was not standard, but dependent on gender and age $(P>0.1)$ and gender, age, and roles $(P<0.1)$ with women and elderly earning less than middle-aged men. On average, the highest fee was

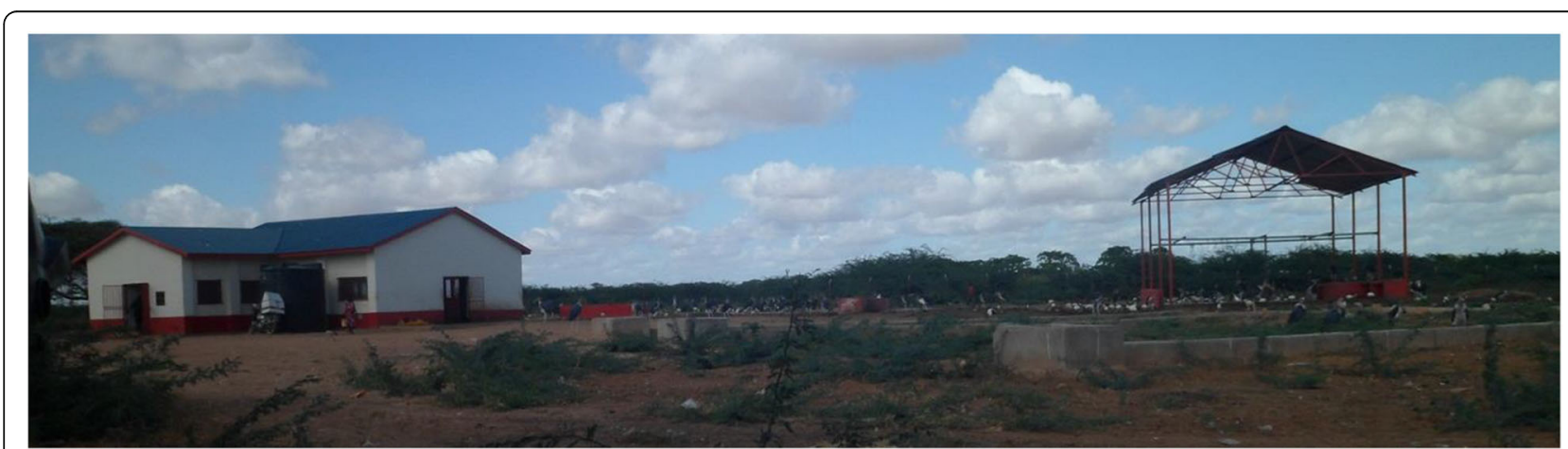

Fig. 3 Pictorial representation of an enclosed slaughterhouse for goats and sheep (left) and an open slaughterhouse for cattle and camel (right) 
USD1.0 $(P<0.1$; range $0.8-1.5)$ paid to the middle-aged butchers per animal slaughtered. Female and elderly butchers were given less prestigious roles such as byproducts handling and waste management and hence a lower income. As the fees were low, the butchers preferred to take red offal as an "in-kind" payment, with majority of the butchers operating subsequent value addition. On average, the butcher earned about USD5.0 $(P>0.1$; range 1.4-7.5) per day.

Meat transportation was hired, and the fees charged were dependent on the weight of carcass, distance to be covered, and personal relationship with the transporter. In the nearby butcheries, meat retail prices were purely dependent on the weight and rarely on the appearance, unlike at the slaughterhouse. The average retail price for raw beef was USD $4.0(P<0.01$; range $4.0-4.4)$ per $\mathrm{kg}$ and camel, goat, and sheep meat retailed at USD 4.4 $(P<0.01$; range $4.2-5.0)$ each. Roasted meat (nyama choma) and stewed and boiled meat (tumbukiza) were common delicacies, and each retailed at an average USD $5.0(P<0.01$; range 4.4-5.5) per portion, with each portion prepared using roughly a kilo of raw meat. On average, the meat retailers made USD $6(P<0.1$; range 2.3-8.2) per day.

Still, within the slaughterhouses, value addition of edible by-products was mainly based on indigenous ethnic techniques such as scalding, boiling, roasting, smoking, deep frying, and sun drying. Each subsequent value addition process came with a $34 \%(P>0.1$; range 19 $62 \%)$ profit margin; for instance, boiled bovine head costs USD $3.0(P<0.01$; range $2.5-3.2)$ and boiled hooves cost USD $0.3(P<0.001$; range $0.3-0.3)$ each, while boiled colon and roasted testicles cost USD 0.2 ( $P>0.1$; range $0.1-0.3$ ) each. Community-specific products were dependent on culture and religion. For instance, the Turkana community made Atienus (Fig. 4a) by dicing fatty tissues (locally referred to as Akuring) into $2 \mathrm{~cm}$ by 2 $\mathrm{cm}$ by $2 \mathrm{~cm}$ chunks and then filling into a goat colon. It was then boiled for about $10 \mathrm{~min}$ and sold at USD 0.3 $(P<0.01$; range $0.1-0.5)$ per piece. In Marsabit County, Chrismirish was prepared by dicing the small intestines into tiny cubes of about $0.5 \mathrm{~cm}$ and then pan-frying the chunks. The average price of Chrismirish sell was USD 0.5 $(P<0.01$; range $0.5-0.6)$ per serving (about $200 \mathrm{~g}$ ).

Traditional sausages, locally referred to as mutura, were common across the pastoral communities and were prepared by stuffing meat trimmings and rendered fatty tissues into the large intestines with raw blood acting as the binding ingredient. The price of the traditional sausages was on average USD $0.1(P<0.01$; range $0.1-0.2)$ for a 5-cm-long piece. Sun-drying of meat and byproducts was common, with salt and vinegar occasionally being added during sun-drying. Deep-fried meat chunks locally referred to as Ng'amorumoru in Turkana
County, Olpurda in Kajiado, and Nyirinyiri or Koche in Marsabit and Garissa Counties were observed. Deepfried and sun-dried meats were occasionally pounded to fibrous-like products locally referred to as Enyas in Turkana and Fonntuma in Marsabit Counties. Smoking of the ethnic packaging containers (locally referred to as Ebur in Turkana County) and spicing during the deep frying of meats were also observed among some communities. Deep-fried, sun-dried, and smoked meat products were considered premium ethnic products, with the deep-fried meats retailing at an average price of USD $14.9(P<0.1$; range $10.0-22.5)$ per $\mathrm{kg}$, while sun-dried with occasional pounding retailing at USD $18.3(P>0.1$; range 10.0-20.0) per kg. During the boiling process of the edible by-products, the resulting soup was homogenized and retailed at USD $0.1(P<0.01$; range $0.1-0.5)$ per serving (about $250 \mathrm{ml}$ ). Occasionally, herbs were added to the soup thereby doubling the price of soup.

As reported in previous research, pastoral communities are increasingly diversifying their economic and social activities through value addition of meat and meat by-products, as well as engaging in crop farming, trade, and craftsmanship (Headey et al. 2014; Rojas-Downing et al. 2017). Cultural diversity during processing was observed among different communities which implies weakening or lost ties among pastoralists (Dabasso et al. 2018; Gichure 2017).

Even though value addition was common, the observed preparation and consumption behaviours were highly dependent on cultural norms, beliefs, and religion. Prime meat cuts and slaughter by-products were consumed by the middle-age traders who were choosy on what to consume with leftovers comprising brains, testicles, bone marrow, fatty tissues, and roasted hides kept aside for the less fortunate. In one case, an elderly trader in Garissa said: "I cannot prepare or cook intestines... I would rather give them to the less fortunate". Gender and age have been seen to influence preparation and consumption behaviours (Mathi et al. 2016).

Traditional containers (locally referred to as Ebur in Turkana and Dhola/Dhibe/Subb in Marsabit) were made from sculptured wood with a leather bottom and lid; these retailed at between USD 2.0 and USD 10.0 depending on size, with the smallest having a capacity of about $250 \mathrm{ml}$ and the largest having a capacity of 21 . These containers were not washed; rather, they were sanitized by fumigation using smoke from Balanites rotundifolia locally known as Elamach or Adung in Turkana. Similar practices have been reported in previous research (Dabasso et al. 2018; Gichure et al. 2014). Figure $4 \mathrm{a}$ and $\mathrm{b}$ are pictorial representations of common ethnic delicacies made using edible slaughter byproducts. 

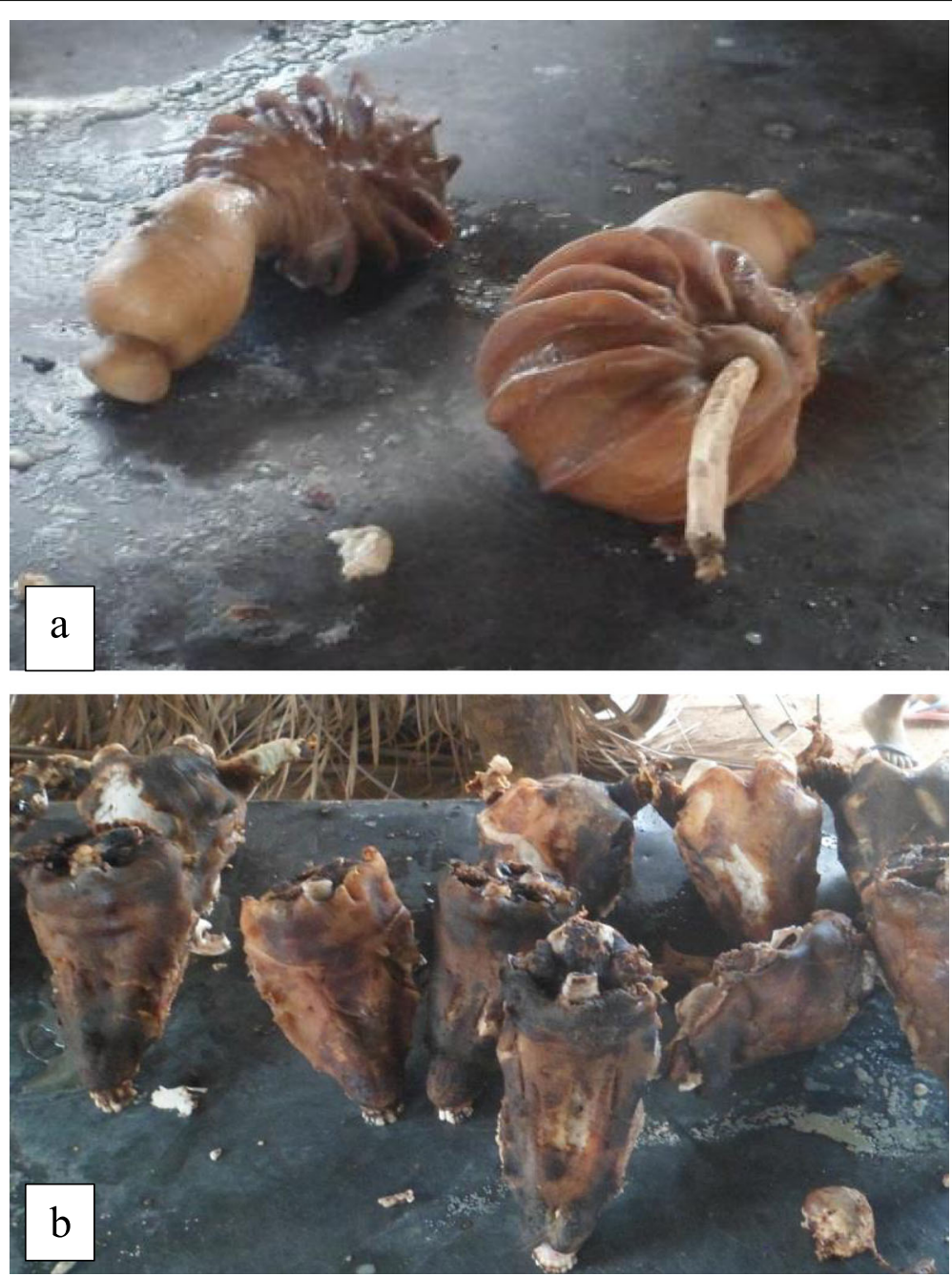

Fig. 4 Pictorial representations of common ethnic delicacies made using edible slaughter by-products. a A photo of Atienus, common among the Turkana community which is made using fatty tissue trimmings stuffed inside the colon and then boiled. $\mathbf{b}$ Scalded and then boiled goat heads, photo taken in Kajiado County

\section{The social dimension of human well-being within slaughterhouses}

Cultural norms and gender played a critical role in natural resources management. Access to capital and financing, land, labour, and information was seen to favour men. Gender and age were seen to influence roles within a slaughterhouse $(P<0.01)$. Mostly, men were involved in seemingly prestigious operations such as slaughtering $(60 \%)$, trade in live animals $(90 \%$ and retail of meat (65\%), while women and youth are involved in seemingly less prestigious jobs such as scalding (85\%), roasting $(85 \%)$, boiling $(60 \%)$, stuffing by-products $(60 \%)$, sale of by-products (75\%), sale of firewood (55\%), water $(55 \%)$, charcoal (55\%), and managing the nearby makeshift shops (70\%). Figure 5 brings out a pictorial representation of gender roles in the slaughterhouses. As seen in the photos, men oversaw livestock marketing (Fig. 5a) and slaughter operations (Fig. 5b) while women are mostly in charge of by-product value addition (Fig. 5c). Similar findings on gender roles and dimensions have been reported in northern Africa (Pedersen and Benjaminsen 2010).

\section{Rangeland management from slaughterhouse dimensions} Diversification into the sale of cooking ingredients such as common salt, herbs, spices, and packaging containers was observed in the surrounding general merchant shops. These shops also supplied foodstuffs, hygienic and hardware products to the residents. Diversification into non-meat products such as the sale of firewood, charcoal, and water was also observed. Minimal diversification into value addition on non-edible by-products was observed. Except for the skins that were salted and then dried, heaps of manure, blood, hooves, bones, and 

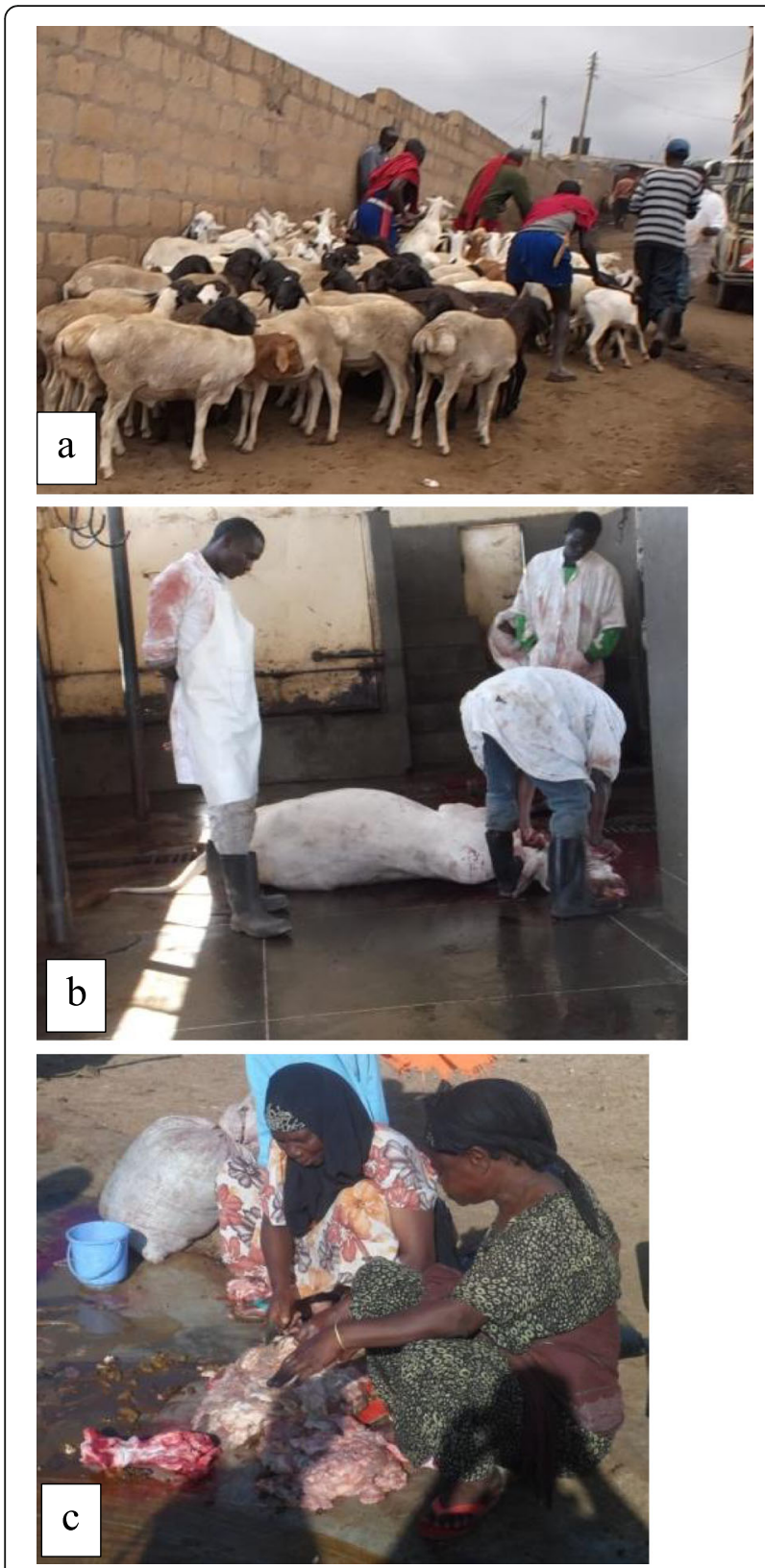

Fig. 5 Pictorial representation of gender dimensions in the slaughterhouses. a Livestock marketing in holding yards in Kajiado County. b Slaughter operations from a slaughterhouse in Marsabit County. c Women cleaning the intestines at a slaughterhouse in Garissa County

horns were occasionally observed in the slaughterhouse yards.

Both economic and material losses were of great concern at the slaughterhouses. At the pre-slaughter stage, the economic losses noted included inappropriate live animal handling resulting in bruises, punctured skins/ hides, weight loss during trekking, internal injuries to the limbs and organs, and in extreme cases death and condemnation of carcasses or organs. Material losses were also seen mainly after slaughter and comprised under-utilization of both the edible and inedible byproducts, spoilage of meat and organs due to inappropriate handling, and drip loss.

During the focus group discussion, one key informant responded "waste management is a big problem to this slaughterhouse. Just look at the heaps of bones and hooves over there. Occasionally, hyenas break-in and scavenge on those bones. Those birds are permanently there feeding on waste blood and searching for meat chunks."

Blood and washing water made the major component of the liquid waste which was simply drained off into a series of lagoons for filtration and evaporation. From all the slaughterhouses visited, only one in Kajiado County utilized liquid waste by using it to generate biogas. Condemned meat/organs were put into condemnation pits in all the slaughterhouses. Manure and underutilized inedible by-products were occasionally given to agropastoralists for crop production as the excess was taken to community grazing yards for soil regeneration and pasture production. The hooves, bones, and horns were used to make ornaments, wood varnish, and animal feed with excess burnt in the slaughterhouse yards. Figure 6 shows a biogas generation system used to manage liquid waste from a slaughterhouse in Kajiado County.

Indigenous knowledge played a big role in the management of natural assets as has been reported in similar work (Lawrence 2012; Lembara et al. 2011; Wheeler and von Braun 2013). Increasing emergence and re-emergence of calamities such as drought, famine, flooding, heatwaves, human-human conflicts, wildfires, epidemic livestock diseases, human-wildlife conflicts, and encroachment of grazing lands with invasive plant species (mainly the Mathenge plant (Prosopis juliflora)) were of concern. Social networks were crucial in the transmission of indigenous and modern knowledge on disaster management as reported. Similar findings on disaster management have been reported (Headey et al. 2014; Rass 2006). Table 1

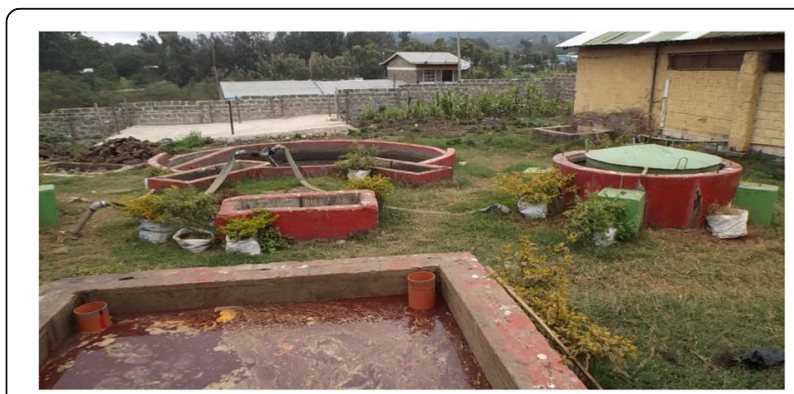

Fig. 6 Biogas generation system for managing liquid waste in a slaughterhouse in Kajiado County 
Table 1 Strategies slaughterhouses use to cope with calamities in the pastoral areas

\begin{tabular}{lll}
\hline Common calamities & Roles slaughterhouses play to cope with the calamities \\
\hline $\mathbf{1}$ Climate change and frequent drought/famine & $\begin{array}{l}\text { Diversification to by-product value addition } \\
\text { Encourage sale and slaughter of animals if drought/famine persists } \\
\text { Develop common grazing rangeland resource management } \\
\text { Collective action for infrastructure development, for example, dykes } \\
\text { and terraces }\end{array}$ \\
& $\begin{array}{l}\text { Develop common grazing land resource management } \\
\text { Encourage reconciliation }\end{array}$ \\
$\mathbf{3}$ Conflicts (clan/community clashes) & $\begin{array}{l}\text { Invest in social capital (networks, associations, welfare groups) } \\
\text { Pre-slaughter inspection }\end{array}$ \\
$\mathbf{5}$ Wild animals' encroachment/wild plants encroachment (e.g. Prosopis) & $\begin{array}{l}\text { Do } \\
\text { grazing lands }\end{array}$ & $\begin{array}{l}\text { Liaise with relevant government institutions } \\
\text { Develop land resource management if a game reserve is around }\end{array}$ \\
$\mathbf{6}$ Wildfires to grazing lands & $\begin{array}{l}\text { Migration } \\
\text { Encourage sale and slaughter of animals if pasture becomes } \\
\text { unavailable } \\
\text { Develop common grazing land resource management }\end{array}$
\end{tabular}

brings out the common calamities and how activities around the slaughterhouses address them.

\section{Conclusion}

This study sought to find how different dimensions of human well-being found within slaughterhouses in the Kenyan ASALs influenced livelihood strategies and outcomes of pastoral communities. The SLA has expounded how these dimensions impact diet diversity, gender and youth inclusiveness, better incomes, and overall improved well-being. The four main areas on the livelihood outcomes that were observed were (i) diversification of economic activities, (ii) personal and household diets and nutrition, (iii) control over and access to resources and income, and (iv) access to roles and opportunities. Slaughterhouses played an integral role in livelihood diversification which is gradually taking place among the pastoral communities visited, with social, economic, and human dimensions taking a central role. Value addition of slaughter by-products provided affordable, safe, high-quality protein diets, with majority of the pastoralists having diversified their diets. Age and gender greatly influenced the roles and thereby the extent of diversification. Value addition of by-products considerably reduced material and economic losses and increased diet range thereby positively impacting natural resources management.

\section{Appendix}

\section{Unstructured interview questions for focus group discussion}

1) Could you please briefly introduce yourselves? Age? Family and household information? Education status? How long have you been working/attached in this slaughterhouse? Do you have another job outside this slaughterhouse?

2) On a normal day, describe all the activities that take place in the slaughterhouse? What is your current role in the slaughterhouse? Describe the institutions and policies that govern operations of this slaughterhouse?

3) What are the prices of all the products found in this slaughterhouse? Meat, red offal, green offal, inedible by-products, and non-meat products. What are the costs, both monetary and non-monetary, incurred in this slaughterhouse?

4) Could you share with me your experiences working in this slaughterhouse? How does working in this slaughterhouse impact your personal life?

5) In this area, describe the common calamities? How have these calamities impacted on the activities and roles within the slaughterhouse? How does the existing trends, urbanization, taboos, and culture affect the operations of this slaughterhouse? Do these affect your roles and duties in the slaughterhouse? What are the obstacles and challenges you face working here?

Abbreviations

ASALs: Arid and semi-arid lands; FAO: Food and Agriculture Organization of the United Nations; FGDs: Focus group discussions; SLA: Sustainable livelihood approach

\section{Acknowledgements}

The authors are grateful for the support offered by their affiliated institutions during the research and manuscript preparation. We also thank the participants of the FGDs and the Directorate of Veterinary Services for their support during the data collection.

Authors' contributions

JNG, the main author, was involved in the whole process from conception and design, acquisition of the data, and analysis and interpretation of the data. He was also involved in drafting the manuscript. SKN made substantial 
inputs during the research process during conception and design, data collection, and analysis. PMM made substantial inputs during conception and design, data collection, and data interpretation. All authors read and approved the final manuscript.

\section{Funding}

Not applicable.

\section{Availability of data and materials}

All data generated or analysed during this study are included in this published article.

\section{Ethics approval and consent to participate}

Approval for this study was obtained from the Directorate of Veterinary Services. Written informed consent was obtained from all participants of a focus group discussion prior to participation.

\section{Consent for publication}

Not applicable.

\section{Competing interests}

The authors declare that they have no competing financial or non-financial interests.

\section{Author details}

'Department of Food Science, Nutrition and Technology, South Eastern Kenya University, P.O. Box 170-90200, Kitui, Kenya. ${ }^{2}$ Department of Land Resource Management \& Agricultural Technology, University of Nairobi, P.O. Box 29053-00625, Kangemi, Kenya. ${ }^{3}$ Quality Assurance Department, Bidco Land O'Lakes Limited, P.O. Box 7029-20100, Nakuru, Kenya.

Received: 26 June 2020 Accepted: 1 November 2020

\section{Published online: 10 December 2020}

\section{References}

Alinovi L, D'Errico M, Mane E, Romano D, 2010. Livelihoods strategies and household resilience to food insecurity: An empirical analysis to Kenya, in: Mobilising European research for development policies. Dakar: European Union and the Food and Agriculture Organization of the United Nations., pp. 1-52. http://www.technicalconsortium.org/wp-content/uploads/2014/05/ Livelihoods-Strategies_Household-Res.pdf.

Anderson, M.D.C. 2015. The role of knowledge in building food security resilience across food system domains. Journal of Environmental Studies and Sciences 5: 543-559. https://doi.org/10.1007/s13412-015-0311-3.

Ansah, I.G.K., C. Gardebroek, and R. Ihle. 2019. Resilience and household food security: A review of concepts, methodological approaches and empirical evidence. Food Security 11: 1187-1203. https://doi.org/10.1007/s12571019-00968-1.

Bhattacharya, J., J. Currie, and S. Haider. 2004. Poverty, food insecurity, and nutritional outcomes in children and adults. Journal of Health Economics 23: 839-862. https://doi.org/10.1016/j.jhealeco.2003.12.008.

Braun, V., and V. Clarke. 2006. Using thematic analysis in psychology. Qualitative Research 3 (2): 77-101. https://doi.org/10.1191/1478088706qp063oa.

Campbell, B.M., S.J. Vermeulen, P.K. Aggarwal, C. Corner-Dolloff, E. Girvetz, A.M Loboguerrero, J. Ramirez-Villegas, T. Rosenstock, L. Sebastian, and P.K. Thornton. 2016. Reducing risks to food security from climate change. Global Food Security 11: 34-43. https://doi.org/10.1016/j.gfs.2016.06.002.

Chandra, Y., and L. Shang. 2017. An RQDA-based constructivist methodology for qualitative research. Qualitative Market Research 20: 90-112. https://doi.org/ 10.1108/QMR-02-2016-0014.

Connolly-Boutin, L., and B. Smit. 2016. Climate change, food security, and livelihoods in sub-Saharan Africa. Regional Environmental Change 16: 385 399. https://doi.org/10.1007/s10113-015-0761-x.

Dabasso, B., H. Roba, A. Makokha, A. Onyango, and J. Maina. 2018. Understanding traditional meat processing knowledge among the Borana pastoralist of northern Kenya. Journal of Food Research 7: 30. https://doi.org/10.5539/jfr. v7n4p30

Degeling, C., and M. Rock. 2020. Qualitative research for One Health: From methodological principles to impactful applications. Frontiers in Veterinary Science 7: 1-13. https://doi.org/10.3389/fvets.2020.00070.
Drewnowski, A., and S. Specter. 2004. Poverty and obesity: The role of energy density and energy costs. [review] [123 refs]. The American Journal of Clinical Nutrition 79: 6-16.

Estrada, S. 2017. Qualitative analysis using R: A free analytic tool. Qualitative Report 22 (4): 956-968.

$F A O, 2002$. The state of food insecurity in the world 2002: Addressing the risk factors common to conflict and food insecurity. Rome: FAO.

FAO, 2016. Analysing resilience for better targeting and action resilience index measurement and analysis-II. Rome: FAO.

Fernández-Giménez, M.E., N.H. Venable, J. Angerer, S.R. Fassnacht, R.S. Reid, and J. Khishigbayar. 2017. Exploring linked ecological and cultural tipping points in Mongolia. Anthropocene 17: 46-69. https://doi.org/10. 1016/j.ancene.2017.01.003.

Gichure, J.N. 2017. Integrating traditional techniques into conventional preservation methods to upgrade pastoral deep-fried beef products in Kenya. PhD. Thesis, Department of Food Science, Nutrition \& Technology, The University of Nairobi.

Gichure, J.N., C.N. Kunyanga, P. Mathi, and J.K. Imungi. 2014. The present status of meat processing and preservation in the pastoral regions of Kenya. Food Science and Quality Management 34: 42-51.

Global Water Partnership Eastern Africa (GWPEA), 2015. Assessment of drought resilience frameworks in the Horn of Africa., Integrated Drought Management Program in the Horn of Africa (IDMP HOA). Entebbe, Uganda.

Headey, D., A.S. Taffesse, and L. You. 2014. Diversification and development in pastoralist Ethiopia. World Development 56: 200-213. https://doi.org/10.1016/j. worlddev.2013.10.015

Huho, J.M., J.N. Mashara, and P.K. Musyimi. 2016. Profiling disasters in Kenya and their causes. Academic Research International 7: 290-305.

Islam, S., N. Cenacchi, T.B. Sulser, S. Gbegbelegbe, G. Hareau, U. Kleinwechter, D. Mason-D'Croz, S. Nedumaran, R. Robertson, S. Robinson, and K. Wiebe. 2016. Structural approaches to modelling the impact of climate change and adaptation technologies on crop yields and food security. Global Food Security 10: 63-70. https://doi.org/10.1016/j.gfs.2016.08.003.

Jackson, G., K.E. McNamara, and B. Witt. 2020. "System of hunger": Understanding causal disaster vulnerability of indigenous food systems. Journal of Rural Studies 73: 163-175. https://doi.org/10.1016/j.jrurstud.2019.10.042.

Krätli, S., Swift, J., 2014. 'Counting pastoralists' in Kenya. Nairobi: DLCl/REGLAP.

Lawrence, G. 2012. Food security. Australian Journal of International Affairs 66: 281-282. https://doi.org/10.1080/10357718.2012.658620.

Lembara, S., Sirak, A., Jenet, A., Gluecks, I., Pissang, C., Obala, E., 2011. Drought contingency planning with pastoral communities. A Community Managed Disaster Risk Reduction Planning toolkit for Humanitarian Workers in the Horn of Africa. Nairobi: IIRR Publishing.

Little, P.D., K. Smith, B.A. Cellarius, D.L. Coppock, and C. Barrett. 2001. Avoiding disaster: Diversification and risk management among East African herders. Development and Change 32: 401-433.

Mathi, P., C. Kunyanga, J.N. Gichure, and J.K. Imungi. 2016. Utilization of beef slaughter by-products among the Kenyan pastoral communities. Food Science and Quality Management 53: 78-83.

Mayanja, M., C. Rubaire-Akiiki, J. Morton, S. Young, and T. Greiner. 2015. Diet diversity in pastoral and agro-pastoral households in Ugandan rangeland ecosystems. Ecology of Food and Nutrition 54: 529-545. https:/doi.org/10.1080/03670244.2015.1041135.

Megersa, B., A. Markemann, A. Angassa, and A. Valle Zárate. 2014. The role of livestock diversification in ensuring household food security under a changing climate in Borana, Ethiopia. Food Security 6: 15-28. https://doi.org/ 10.1007/s12571-013-0314-4.

Musyoka, P.K., J. Onjala, and L.P. Mureithi. 2020. Infrastructure growth, household vulnerability and response to shocks in Kenya. African Journal of Economic Review VIII: 125-143.

Napoli, M., P. De Muro, and M. Mazziotta. 2011. Towards a food insecurity multidimensional index (FIMI). Unpublished Masters Thesis, Roma Tre University, Rome, Italy.

Nyariki, D.M., and D.A. Amwata. 2019. The value of pastoralism in Kenya: Application of total economic value approach. Pastoralism 9. https://doi.org/ 10.1186/s13570-019-0144-X.

Oluoko-Odingo, A.A. 2011. Vulnerability and adaptation to food insecurity and poverty in Kenya. Annals of the Association of American Geographers 101: 1 20. https://doi.org/10.1080/00045608.2010.532739.

Onwuegbuzie, A.J., and R.K. Frels. 2015. A framework for conducting critical dialectical pluralist focus group discussions using mixed research techniques. Journal of Education 1: 159. https://doi.org/10. 5296/jei.v1i2.8662 
Opiyo, F., O. Wasonga, M. Nyangito, J. Schilling, and R. Munang. 2015. Drought adaptation and coping strategies among the Turkana pastoralists of northern Kenya. International Journal of Disaster Risk Science 6: 295-309. https://doi. org/10.1007/s13753-015-0063-4.

Pedersen, J., and T.A. Benjaminsen. 2010. Food security and pastoralism in the northern Sahel. In Human Ecology, ed. D.G. Bates and J. Tucker, 1-377. Boston: Springer. https://doi.org/10.1007/978-1-4419-5701-6.

Pérez-Escamilla, R., M.B. Gubert, B. Rogers, and A. Hromi-Fiedler. 2017. Food security measurement and governance: Assessment of the usefulness of diverse food insecurity indicators for policy makers. Global Food Security 14 96-104. https://doi.org/10.1016/j.gfs.2017.06.003.

Pinstrup-Andersen, P. 2009. Food security: Definition and measurement. Food Security 1: 5-7. https://doi.org/10.1007/s12571-008-0002-y.

Quandt, A. 2018. Measuring livelihood resilience: The Household Livelihood Resilience Approach (HLRA). World Development 107: 253-263. https://doi. org/10.1016/j.worlddev.2018.02.024.

Rass, N. 2006. Policies and strategies to address the vulnerability of pastoralists in sub-Saharan Africa, Pro-poor Livestock Policy Initiative (PPLPI). Rome: FAO.

Rojas-Downing, M.M., A.P. Nejadhashemi, T. Harrigan, and S.A. Woznicki. 2017. Climate change and livestock: Impacts, adaptation, and mitigation. Climate Risk Management 16: 145-163. https://doi.org/10. 1016/j.crm.2017.02.001

Sati, V.P., and L. Vangchhia. 2017. A sustainable livelihood approach to poverty reduction: An empirical analysis of Mizoram, the eastern extension of the Himalaya. Switzerland: Springer International Publishing. https://doi.org/10. 1007/978-3-319-45623-2

Saukko, P., 2018. Methodologies for cultural and social studies in an age of new technologies, in: Denzin, N.K., Lincoln, Y.S. (Eds.), The SAGE Handbook of Qualitative Research. SAGE, pp. 466-490. https://doi.org/10.1007/s11229-0171319-x.

Serrat, O. 2017. The sustainable livelihoods approach, in: Knowledge solutions, 2126. Singapore: Springer. https://doi.org/10.1007/978-981-10-0983-9.

Walker, B., C.S. Holling, S.R. Carpenter, and A. Kinzig. 2004. Resilience, adaptability and transformability in social-ecological systems. Ecology and Society 9. https://doi.org/10.5751/ES-00650-090205.

Wheeler, T., and J. von Braun. 2013. Climate change impacts on global food security. Science 341: 508-513.

Zezza, A., and L. Tasciotti. 2010. Urban agriculture, poverty, and food security: Empirical evidence from a sample of developing countries. Food Policy 35: 265-273. https://doi.org/10.1016/j.foodpol.2010.04.007.

\section{Publisher's Note}

Springer Nature remains neutral with regard to jurisdictional claims in published maps and institutional affiliations.

\section{Submit your manuscript to a SpringerOpen ${ }^{\odot}$ journal and benefit from:}

- Convenient online submission

- Rigorous peer review

- Open access: articles freely available online

High visibility within the field

- Retaining the copyright to your article

Submit your next manuscript at $\boldsymbol{\nabla}$ springeropen.com 